\title{
APLIKASI REGRESI ORDINAL PADA FAKTOR YANG BERPENGARUH TERHADAP AKTIFITAS ENZIM CHOLINESTERASE DARAH (Studi di Dusun Binangun Desa Bumiaji Kecamatan Bumiaji Kota Batu)
}

\section{THE APPLICATION OF ORDINAL REGRESSION ON THE INFLUENCING FACTORS OF THE CHOLINESTERASE ENZYME OF BLOOD ACTIVITY (Study in Binangun Sub-village, Bumiaji Village, Bumiaji Subdistrict, Batu City)}

\author{
Diky Novariyanto ${ }^{1}$, Arief Wibowo ${ }^{1}$ \\ ${ }^{1}$ Departemen Biostatistika dan Kependudukan \\ Fakultas Kesehatan Masyarakat, Universitas Airlangga, Surabaya, Indonesia \\ Alamat Korespondensi: Diky Novariyanto \\ Email: ronaldikin88@gmail.com
}

\begin{abstract}
The case of pesticide contamination in Batu City in 2017 was relatively high, with the percentage of $82.7 \%$. The case of pesticide contamination could be detected by examining the cholinesterase enzyme activity in blood. The Bumiaji villagers (Batu City) mostly work as a pesticide spray farmers. The study aims to analyze the factors that affect cholinesterase enzyme's activities on the blood of the farmers who spray pesticide. The study was observational with cross-sectional design and used ordinal regression method. The research samples were 81 farmers selected through accidental sampling method. The independent variables of this study were the use of Personal Protective Equipment (PPE) and farmers' work duration. The dependent variable of this study was the cholinesterase enzyme's activities in the farmers' blood. The results of the study were that most farmers experienced cholinesterase enzyme activity changes, misused PPE (80.2\%), and worked for less than 8 hours each day (92.6\%). Based on the ordinal regression analysis, the variables which affected to the cholinesterase enzyme activity of the farmers' blood was the use of PPE with a p-value of $0.00<\alpha(0.05)$. Based on the regression model, the farmers who properly used PPE had 0.12 higher chance to avoid the change of cholinesterase enzyme activity in the blood. It is necessary to held a dissemination about the use of personal protective equipment to the farmers, as a preventive effort by the district health office, local village office, and the management of farmer groups in Binangun sub-village, Bumiaji Village, Bumiaji Subdistrict, Batu City.
\end{abstract}

Keywords: Cholinesterase enzyme activity, pesticide, farmers

\begin{abstract}
ABSTRAK
Kasus kontaminasi pestisida di Kota Batu pada tahun 2017 cukup tinggi, dengan persentase sebesar 82,7\%. Kasus kontaminasi pestisida dapat dideteksi dengan pemeriksaan aktifitas enzim cholinesterase darah. Penduduk Desa Bumiaji sebagian besar berprofesi sebagai petani penyemprot pestisida. Penelitian ini bertujuan untuk menganalisis faktor yang berpengaruh terhadap aktifitas enzim cholinesterase darah petani. Penelitian ini merupakan penelitian observasional dengan rancang bangun cross sectional dan menggunakan metode regresi ordinal. Populasi penelitian ini sebanyak 100 petani, dengan sampel penelitian sebanyak 81 petani yang dipilih secara accidental sampling dari kelompok petani Bumijaya II dan Bumi Abadi Utara. Penelitian ini dilaksanakan di Dusun Binangun Desa Bumiaji Kecamatan Bumiaji Kota Batu. Variabel independen (faktor) penelitian yaitu pemakaian kelengkapan Alat Pelindung Diri (APD) dan karakteristik petani (lama kerja). Variabel dependen penelitian yaitu aktifitas enzim cholinesterase darah petani. Hasil penelitian adalah sebagian besar petani mengalami perubahan aktifitas enzim cholinesterase darah, petani yang tidak menggunakan kelengkapan APD sesuai aturan (80,2\%), dan bekerja selama kurang dari 8 jam perhari (92,6\%). Berdasarkan analisis regresi ordinal, faktor yang berpengaruh terhadap aktifitas enzim cholinesterase darah petani adalah pemakaian kelengkapan APD dengan nilai $p(0,00)$ kurang dari $\alpha(0,05)$. Berdasarkan model regresi ordinal yang tersusun, petani yang memakai kelengkapan APD sesuai aturan berpeluang 0,12 kali lebih besar untuk terhindar dari perubahan aktifitas enzim cholinesterase darah. Perlu adanya kegiatan sosialisasi penggunaan alat pelindung diri kepada petani sebagai upaya preventif yang dilakukan oleh dinas kesehatan, perangkat desa dan pengurus kelompok petani di Dusun Binangun Desa Bumiaji Kecamatan Bumiaji Kota Batu.
\end{abstract}

Kata kunci: aktifitas enzim cholinesterase, pestisida, petani 


\section{PENDAHULUAN}

Pestisida merupakan bahan kimia, campuran atau bahan-bahan lain yang bersifat bioaktif. Pestisida telah dimanfaatkan secara luas di berbagai bidang kehidupan masyarakat, terutama dalam bidang pertanian (Raini, 2007). Penggunaan pestisida dalam bidang pertanian sudah menjadi hal yang wajar. Pestisida sering digunakan untuk memberantas hama dan penyakit pada tanaman, baik buah, sayur, dan tanaman hias. Bahkan, dewasa ini, petani sudah semakin akrab dengan sarana produksi pestisida, meski penggunaannya berpotensi menimbulkan dampak negatif, baik bagi pengguna, konsumen, dan lingkungan, serta akan berdampak pula pada sosial ekonomi masyarakat (Wibowo, 2017).

Menurut Djojosumarto dalam (Novarianto, 2017) Pestisida pada dasarnya bersifat racun dan berpotensi mengandung bahaya. Ketidakbijaksanaan dalam penggunaan pestisida dapat menimbulkan beberapa dampak negatif bagi pengguna. Pestisida bisa mengkontaminasi pengguna secara langsung sehingga mengakibatkan keracunan. Keracunan yang diderita oleh pengguna dapat berupa keracunan akut ringan dengan gejala sakit kepala, iritasi kulit ringan, badan terasa sakit, dan diare; keracunan akut berat yang dirasakan adalah mual, menggigil, kejang perut, sulit bernafas, keluar air liur, pupil mata mengecil, dan denyut nadi meningkat, bahkan bisa mengakibatkan kematian; dan keracunan dalam jangka waktu lama (kronis) yang dapat menimbulkan gangguan kesehatan, diantaranya iritasi mata dan kulit, cacat pada bayi, kanker, mutasi gen, gangguan endokrin, gangguan reproduksi, tetratogenesis, blood disorder serta gangguan saraf, hati, ginjal dan pernafasan.

Pestisida yang paling banyak digunakan di Indonesia adalah pestisida jenis organofosfat (Desimal, 2013). Pestisida organofosfat dapat masuk ke dalam tubuh melalui alat pencernaan atau digesti, saluran pernafasan atau inhalasi dan melalui permukaan kulit yang tidak terlindungi atau penetrasi. Apabila pestisida golongan organofosfat mengkontaminasi manusia dalam jangka waktu lama, maka dapat menimbulkan efek berupa kontaminasi (keracunan) pestisida kronis yang akan berpotensi karsinogen pada tubuh manusia (Novarianto, 2013).

Enzim cholinesterase secara normal bertugas menghidrolisis senyawa asetilkolin menjadi asetat dan kholin. Pada saat aktifitas enzim cholinesterase terhambat dapat mengakibatkan peningkatan jumlah senyawa asetilkolin yang mengikat reseptor muskarinik dan nikotinik pada sistem saraf pusat dan perifer. Hal ini dapat menyebabkan timbulnya gejala keracunan yang berpengaruh pada seluruh tubuh (Karyadi, 2008). Kasus kontaminasi pestisida organofosfat dapat dideteksi dengan pemeriksaan aktifitas enzim cholinesterase darah dengan menggunakan Tintometer Kit (Sutrisna, 2011).

Cholinesterase yaitu suatu enzim yang terdapat pada cairan ekstra seluler yang berfungsi menghentikan aksi dari asethilcholin dengan jalan menghidrolisa menjadi kholin dan asam asetat. Asetilcholin adalah suatu neurohormon yang terdapat antara ujung-ujung saraf dan otot sebagai media kimia yang fungsinya meneruskan rangsangan saraf/impuls ke reseptor sel-sel otot dan kelenjar (Guntur, 2014). Pestisida yang masuk kedalam tubuh, baik melalui kulit, mulut dan saluran pencernaan serta saluran pernafasan akan berpengaruh terhadap aktifitas enzim cholinesterase. Apabila enzim cholinesterase dalam tubuh terikat oleh pestisida jenis organofosfat, maka kerja saraf akan terganggu. Dengan demikian gerak otot tidak dapat dikendalikan, akhirnya terjadi kekejangan, lumpuh atau pingsan yang bisa menyebabkan kematian (Guntur, 2014). 
Tabel 1. Pengukuran Aktifitas Enzim Cholinesterase Darah

\begin{tabular}{|c|c|c|}
\hline $\begin{array}{c}\text { Aktifitas } \\
\text { Cholinesterase }\end{array}$ & $\begin{array}{c}\text { Tingkat } \\
\text { Keracunan }\end{array}$ & Tindakan Penyelamatan \\
\hline $76 \%-100 \%$ & Normal & $\begin{array}{l}\text { Dapat terus bekerja, namun perlu pemeriksaan } \\
\text { berkala }\end{array}$ \\
\hline $51 \%-75 \%$ & Keracunan Ringan & $\begin{array}{l}\text { Melakukan pemeriksaan ulang, jika hasilnya sama, } \\
\text { pekerja dijauhkan dari pestisida organfosfat, } \\
\text { kemudian melakukan pemeriksaan ulang dalam } \\
\text { waktu } 2 \text { minggu. }\end{array}$ \\
\hline $26 \%-50 \%$ & $\begin{array}{l}\text { Keracunan } \\
\text { Sedang: }\end{array}$ & $\begin{array}{l}\text { Melakukan pemeriksaan ulang, jika hasilnya sama, } \\
\text { menghentikan paparan pestisida pada pekerja, dan } \\
\text { bila ditemukan gejala perlu memberikan pemeriksaan } \\
\text { dokter. }\end{array}$ \\
\hline $0 \%-25 \%$ & $\begin{array}{l}\text { Keracunan Berat } \\
\text { dan sangat } \\
\text { berbahaya }\end{array}$ & $\begin{array}{l}\text { Melakukan pemeriksaan ulang dan melarang pekerja } \\
\text { untuk bekerja sampai ada rekomendasi dari dokter. }\end{array}$ \\
\hline
\end{tabular}

Sumber: Novariyanto, 2013

Berdasarkan penelitian terdahulu (Asyim, 2009); (Wanodya, 2011) dan (Novariyanto, 2013), menyatakan bahwa perubahan aktifitas enzim cholinesterase darah yang disebabkan oleh kontaminasi pestisida dapat diklasifikasikan menjadi empat tingkatan yaitu kategori normal, keracunan ringan, keracunan sedang dan keracunan berat. Pengukuran tingkat aktifitas enzim cholinesterase darah dapat digolongkan pada tabel 1 .

Organisasi kesehatan dunia (WHO) memperkirakan setiap tahun terjadi sekitar 25 juta kasus kontaminasi pestisida atau sekitar 68.493 kasus setiap hari. Salah satu penelitian di Multan Pakistan, selama tahun 1996-2000 menemukan 578 pasien yang keracunan di suatu rumah sakit. Sebanyak 370 pasien terdiagnosa kasus kontaminasi pestisida dengan korban jiwa sebanyak 54 orang yaitu terjadi pada petani atau pekerja di bidang pertanian (Raini, 2007). Di Indonesia, ketergantungan petani akan pestisida dapat dilihat dari peningkatan penggunaan pestisida dari 11.587,2 ton pada tahun 1998 menjadi $17.977,2$ ton pada tahun 2000. Pestisida jenis organofosfat banyak diaplikasikan pada tanaman hortikultura, terutama tanaman sayuran (Hasibuan, 2015).

Kasus kontaminasi pestisida di Kota Batu mayoritas dialami oleh para petani. Sebesar $82,7 \%$ petani di Kota Batu mengalami kasus kontaminasi pestisida (Dinkes, 2017). Tidak semua kasus kontaminasi pestisida menyebabkan korban jiwa, namun seluruh kasus telah terbukti diakibatkan oleh kontaminasi pestisida. Data Departemen Kesehatan Republik Indonesia tentang monitoring kontaminasi pestisida organofosfat pada petani yang terdapat di 27 provinsi menunjukkan bahwa $38,18 \%$ petani mengalami kontaminasi pestisida dengan rincian berikut: $1,3 \%$ petani mengalami keracunan berat; $9,98 \%$ petani terindikasi keracunan sedang; dan $26,89 \%$ petani keracunan ringan (Raini, 2007).

Berdasarkan litbangkes Dinas Kesehatan Kota Batu pada tahun 2012 kepada 330 petani yang tersebar di 3 kecamatan (Kecamatan Batu, Bumiaji dan Junrejo), didapatkan hasil sebagian besar petani $(73,5 \%)$ mengalami keracunan ringan. Sebanyak $75 \%$ petani yang mengalami keracunan ringan berdomisili di Kecamatan Bumiaji. Hasil produksi pertanian di Kecamatan Bumiaji didominasi oleh tanaman hias dan holtikultura. Kecamatan Bumiaji merupakan sektor pertanian terbesar di Kota Batu. Sebanyak 27,84\% penduduk Desa Bumiaji berprofesi sebagai petani, bahkan di Desa Bumiaji terdapat 6 kelompok petani yang aktif bekerja sebagai petani penyemprot pestisida (profil Desa Bumiaji, 2015). Kondisi tersebut 
menjadikan petani di Desa Bumiaji memiliki risiko tinggi untuk terkontaminasi pestisida (Desimal, 2013). Perubahan aktifitas enzim cholinesterase darah petani dapat dihubungkan dengan beberapa faktor. Berdasarkan hasil penelitian Asyim (2009), Wanodya (2011) dan Novariyanto (2013); faktor-faktor yang berhubungan dengan kejadian kontaminasi pestisida adalah pemakaian kelengkapan Alat Pelindung Diri (APD) dan lama kerja petani. Berdasarkan peraturan Dirjen PP dan PL tahun 1993 dalam (Novariyanto, 2013) persyaratan alat pelindung diri yang dipakai petani pada saat melakukan penyemprotan pestisida di luar ruangan adalah sepatu boots, baju lengan panjang, celana panjang, topi, sarung tangan dan masker. Pemakaian kelengkapan APD dikatakan tidak sesuai aturan apabila tidak memakai salah satu dari keenam perlengkapan tersebut. Sedangkan menurut Suma'mur dalam (Novariyanto, 2017) menyatakan bahwa persyaratan lama waktu bekerja seseorang dalam satu hari adalah 8 jam perhari.

Keempat penelitian terdahulu menggunakan metode chi square guna mengidentifikasi variabel independen (faktor) yang berpengaruh, namun tidak pada besar pengaruh dari masing-masing variabel independen tersebut (Abdhidama, 2015). Metode chi square tidak bisa memberikan gambaran kausalitas (sebabakibat). Berdasarkan uraian diatas maka metode statistik yang tepat digunakan dalam penelitian ini adalah metode regresi ordinal. Metode regresi ordinal (Fattah, 2013) dapat digunakan ketika variabel dependen berbentuk data kategori/ordinal dan variabel independen berbentuk data kategori atau kontinyu. Aktifitas enzim cholinesterase darah berperan sebagai variabel dependen dalam penelitian ini.

Penelitian ini bertujuan untuk menganalisis faktor (pemakaian kelengkapan APD dan lama kerja petani) yang berpengaruh terhadap aktifitas enzim cholinesterase darah petani di Desa
Bumiaji Kecamatan Bumiaji Kota Batu. Langkah ini merupakan salah satu upaya untuk mencegah dan mengendalikan faktor yang berpengaruh terhadap kasus kontaminasi pestisida.

\section{METODE PENELITIAN}

Penelitian ini merupakan penelitian observasional, peneliti tidak memberikan perlakuan pada objek penelitian (Qudratullah, 2013). Berdasarkan waktu penelitian, penelitian ini termasuk cross sectional study, kemudian data dianalisis statistik menggunakan metode regresi ordinal. Penelitian berlangsung pada bulan Maret 2017, di Dusun Binangun Desa Bumiaji Kecamatan Bumiaji Kota Batu. Populasi dalam penelitian ini adalah petani tanaman hias dan holtikulutra yang berjumlah 100 orang, berasal dari kelompok petani Bumijaya II dan Bumi Abadi Utara. Sampel dalam penelitian terdiri dari 81 responden yang berasal dari kelompok Bumijaya II sebanyak 45 orang responden dan 36 orang responden dari kelompok Bumi Abadi Utara. Teknik pengambilan sampel yang digunakan adalah teknik accidental sampling (Latan, 2014); karena sampel dalam penelitian bertepatan dengan sampel pemeriksaan aktifitas enzim cholinesterase darah yang dilakukan oleh Dinas Kesehatan Kota Batu.

Variabel independen (faktor) dalam penelitian ini meliputi: data pemakaian kelengkapan APD dan karakteristik petani, yakni lama kerja. Sedangkan variabel dependen adalah aktifitas enzim cholinesterase darah petani. Data pemakaian kelengkapan APD dan karakteristik petani (lama kerja) merupakan data primer. Sedangkan data sekunder penelitian adalah data aktifitas enzim cholinesterase darah petani.

Pada penelitian ini faktor pemakaian kelengkapan APD dikategorikan menjadi dua, yakni: pemakaian kelengkapan APD sesuai aturan dan pemakaian kelengkapan APD tidak 
sesuai aturan. Sedangkan faktor lama kerja terbagi menjadi dua kategori yaitu: lama kerja kurang dari 8 jam perhari dan lama kerja lebih dari sama dengan delapan jam perhari.

Data pemakaian kelengkapan APD dan karakteristik petani (lama kerja) diperoleh melalui wawancara pada responden yang dibantu oleh dua orang enumerator menggunakan kuesioner penelitian. Selain itu, data primer juga dikumpulkan melalui kegiatan observasi lapangan menggunakan lembar observasi. Pengumpulan data primer dengan cara menyebar kuisioner yang dilakukan pada saat kegiatan pemeriksaan aktifitas enzim cholinesterase darah petani oleh Dinas Kesehatan Kota Batu.

Hasil pengamatan selanjutnya dicatat pada lembar pengamatan. Data kelengkapan APD petani dikategorikan menjadi dua, yaitu penggunaan kelengkapan APD sesuai aturan dan penggunan kelengkapan APD tidak sesuai aturan. Sedangkan karakteristik petani (lama kerja) digolongkan menjadi dua kategori, yaitu: lama kerja lebih dari 8 jam/hari dan lama kerja kurang dari sama dengan $8 \mathrm{jam} / \mathrm{hari}$. Sedangkan aktifitas enzim cholinesterase darah petani diperoleh dari data Dinas Kesehatan Kota Batu. Peneliti ikut serta dalam kegiatan pemeriksaan aktifitas enzim cholinesterase darah petani yang dilakukan oleh Dinas Kesehatan Kota Batu dalam runtutan kegiatan pada tahun 2016. Data yang telah diperoleh selanjutnya dikategorikan.

Pengklasifikasian aktifitas enzim cholinesterase menjadi 4 tingkatan yakni: normal, keracunan ringan, keracunan sedang dan keracunan berat. Pengklasifikasian itu berdasarkan peraturan Dirjen PP dan PL tahun 1993 (Novariyanto, 2013). Berdasarkan tingkatan tersebut data aktifitas enzim cholinesterase dapat diolah dengan metode regresi ordinal (Iban, 2017).

Keseluruhan data yang telah didapat, hasilnya direkapitulasi dalam bentuk tabel, kemudian data dimasukkan dalam program statistik. Data yang telah dientry diuji multikolinearitas kemudian dianalisis menggunakan metode regresi ordinal (Fattah, 2013).

Menurut Iban (2017), data yang telah diuji multikolinearitas dilanjutkan dengan uji kesesuaian model guna mengetahui apakah model regresi ordinal yang didapat sudah sesuai untuk menggambarkan hubungan antara variabel dependen dengan variabel independen. Kemudian menentukan model terbaik regresi ordinal. Metode regresi ordinal dapat memberikan ketepatan dalam melakukan prediksi suatu kejadian. Penelitian ini telah memperoleh keterangan lolos kaji etik dari Komisi Etik FKM No : 65-KEPK.

\section{HASIL}

\section{Analisis Deskriptif}

Analisis deskriptif dilakukan untuk melihat distribusi data dari variabel variabel penelitian. Berdasarkan hasil penelitian (tabel 2) dapat diketahui bahwa proporsi aktifitas enzim cholinesterase darah pada petani di Dusun Binangun Desa Bumiaji hanya sebesar $17,3 \%$ (14 orang petani) yang memiliki aktifitas enzim cholinesterase normal. Lebih dari 50\% petani diindikasikan mengalami keracunan pestisida dengan proporsi sebagian besar pada kondisi keracunan ringan yaitu sebesar $58,0 \%$ (47 orang petani). $24,7 \%$ (20 orang petani) berada pada kondisi keracunan sedang, dengan proporsi petani di kelompok Bumijaya II lebih tinggi, yakni sebesar $16 \%$ (13 orang petani). Sebesar $8,6 \%$ (7 orang petani) yang mengalami keracunan pestisida pada kondisi keracunan sedang merupakan petani dari kelompok Bumi Abadi Utara.

Berdasarkan hasil penelitian (Tabel 3) dapat diketahui bahwa petani di Dusun Binangun Desa Bumiaji hanya sebesar $19,8 \%$ (16 orang petani) yang menggunakan kelengkapan APD sesuai aturan. Banyak petani yang tidak menggunakan kelengkapan APD sesuai 
aturan, yaitu sebesar $80,2 \%$ (65 orang petani). Proporsi pemakaian kelengkapan APD yang tidak sesuai aturan lebih banyak ditemukan pada petani dari kelompok Bumijaya II, yakni sebanyak 43,2\% (35 orang petani), dibandingkan dengan petani dari kelompok Bumi Abadi Utara, yakni sebanyak 37\% (30 orang petani).

Berdasarkan hasil penelitian (tabel 4) dapat diketahui bahwa sebagian besar (92,6\% atau sebanyak 75 orang) petani di Dusun Binangun Desa Bumiaji memiliki lama kerja kurang dari 8 jam setiap harinya. Berdasarkan Tabel 3 dapat dilihat bahwa proporsi petani dengan lama kerja kurang dari 8 jam perhari pada kelompok petani Bumijaya II lebih tinggi $(49,4 \%)$ dibandingkan petani dari kelompok petani Bumi Abadi Utara (43,2\%).

\section{Analisis Regresi Ordinal}

Berdasarkan uji multikolinearitas pada tabel 5, faktor pemakaian kelengkapan APD petani memiliki nilai tolerance $(0,393$ lebih dari 0,1$)$ dan nilai VIF (2,547 kurang dari 10), sehingga dapat disimpulkan bahwa pemakaian kelengkapan APD tidak bersifat multikolinearitas. Selanjutnya untuk faktor lama kerja petani penyemprot pestisida memiliki nilai tolerance $(0,287$ lebih dari 0,1$)$ dan nilai VIF (3,489 kurang dari 10), kesimpulannya adalah faktor lama kerja tidak bersifat multikolinearitas. Berdasarkan hasil uji multikolinearitas, kedua faktor tersebut tidak bersifat multikolinearitas maka analisis regresi ordinal dapat dilakukan (Palupi, 2013).

Tabel 2. Distribusi Data Aktifitas Enzim Cholinesterase Darah Petani di Dusun Binangun Desa Bumiaji Kota Batu 2017

\begin{tabular}{lcccccc}
\hline \multirow{2}{*}{$\begin{array}{c}\text { Aktifitas Enzim } \\
\text { Cholinesterase }\end{array}$} & Bumijaya II & $\boldsymbol{\%}$ & $\begin{array}{c}\text { Kumi Abadi } \\
\text { Utara }\end{array}$ & $\boldsymbol{\%}$ & Total & \% \\
\hline Keracunan sedang & 13 & 16 & 7 & 8,6 & 20 & 24,7 \\
Keracunan ringan & 24 & 29,6 & 23 & 28,4 & 47 & 58,0 \\
Normal & 8 & 9,9 & 6 & 7,4 & 14 & 17,3 \\
\hline Total & 45 & 55,6 & 36 & 44,4 & 81 & 100 \\
\hline
\end{tabular}

Tabel 3. Distribusi Data Pemakaian Kelengkapan APD Petani di Dusun Binangun Desa Bumiaji Kota Batu 2017

\begin{tabular}{lcccccc}
\hline \multirow{2}{*}{$\begin{array}{c}\text { Pemakaian } \\
\text { Kelengkapan APD }\end{array}$} & Bumijaya II & $\boldsymbol{\%}$ & $\begin{array}{c}\text { Kumi Abadi } \\
\text { Utara }\end{array}$ & \% & Total & \% \\
\cline { 2 - 6 } & & & & & & \\
\hline Tidak sesuai aturan & 35 & 43,2 & 30 & 37 & 65 & 80,2 \\
Sesuai aturan & 10 & 12,3 & 6 & 7,4 & 16 & 19,8 \\
\hline Total & 45 & 55,6 & 36 & 44,4 & 81 & 100 \\
\hline
\end{tabular}

Tabel 4. Distribusi Data Lama Kerja Petani di Dusun Binangun Desa Bumiaji Kota Batu 2017

\begin{tabular}{|c|c|c|c|c|c|c|}
\hline \multirow[b]{2}{*}{ Lama Kerja } & \multicolumn{4}{|c|}{ Kelompok Petani } & \multirow[b]{2}{*}{ Total } & \multirow[b]{2}{*}{$\%$} \\
\hline & Bumijaya II & $\%$ & $\begin{array}{c}\text { Bumi Abadi } \\
\text { Utara }\end{array}$ & $\%$ & & \\
\hline$<8$ jam/hari & 40 & 49,4 & 35 & 43,2 & 75 & 92,6 \\
\hline$\geq 8 \mathrm{jam} / \mathrm{hari}$ & 5 & 6,2 & 1 & 1,2 & 6 & 7,4 \\
\hline Total & 45 & 55,6 & 36 & 44,4 & 81 & 100 \\
\hline
\end{tabular}

Tabel 5. Uji Multikolinearitas

\begin{tabular}{clcc}
\hline \multirow{2}{*}{ No } & \multicolumn{2}{|}{ Variabel } & \multicolumn{2}{c}{ Collinearity statistics } \\
\cline { 3 - 4 } & & Tolerance & VIF \\
\hline 1 & Pemakaian kelengkapan APD & 0,393 & 2,547 \\
2 & Lama kerja & 0,913 & 1,095 \\
\hline
\end{tabular}


Tabel 6. Analisis Regresi Ordinal

\begin{tabular}{|c|c|c|c|}
\hline \multicolumn{2}{|r|}{ Variabel } & \multicolumn{2}{|c|}{$\begin{array}{c}\text { Estimate } \\
\left(\text { Beta / } \boldsymbol{\beta}_{0}\right)\end{array}$} \\
\hline \multirow[t]{2}{*}{ Dependen } & \multirow{2}{*}{$\begin{array}{l}\text { Aktifitas enzim cholinesterase darah } \\
\text { Variabel }\end{array}$} & \multicolumn{2}{|c|}{$-2,675$} \\
\hline & & $\begin{array}{c}\text { Estimate } \\
\left(\text { Beta } / \beta_{1}\right)\end{array}$ & P. value \\
\hline \multirow[t]{2}{*}{ Independen } & Pemakaian kelengkapan APD & $-5,652$ & $\mathbf{0 , 0 0}$ \\
\hline & Lama kerja & $-3,357$ & 0,98 \\
\hline
\end{tabular}

Hasil analisis regresi ordinal menunjukkan bahwa faktor pemakaian kelengkapan APD memiliki nilai $p$. value 0,00 kurang dari nilai alpha 0,05 ; sedangkan faktor lama kerja memiliki nilai $P$ value 0,98 lebih dari nilai alpha 0,05 . Sehingga dapat disimpulkan bahwa faktor pemakaian kelengkapan APD berpengaruh terhadap aktifitas enzim cholinesterase darah.

Model regresi ordinal yang terbentuk (Greene, 2012); yaitu:

$$
\begin{gathered}
\beta_{0}=-2,675 \\
\beta_{1}=-5,652 \\
P_{i}=\frac{1}{\beta_{0}+\beta_{1} X_{1}+\beta_{2} X_{2}+\cdots+\beta_{i} X_{i}} \\
P_{i}=\frac{1}{-2,675-5,652 X_{1}}
\end{gathered}
$$

\section{PEMBAHASAN}

Hasil penelitian ini menunjukkan bahwa faktor yang berpengaruh adalah faktor pemakaian kelengkapan APD. Berdasarkan (Tabel 2) sebagian besar petani di Dusun Binangun Desa Bumiaji Kecamatan Bumiaji Kota Batu memiliki aktifitas enzim cholinesterase darah kategori keracunan ringan dengan jumlah $58 \%$ (47 orang petani) dan tidak memakai kelengkapan APD sesuai aturan sebanyak $80,2 \%$ (65 orang petani). Kedua hal tersebut memiliki keterkaitan.

Petani dari kelompok Bumijaya II yang memiliki aktifitas enzim cholinesterase darah kategori keracunan ringan sebanyak 29,6\% (24 orang petani), sedangkan petani dari kelompok Bumi
Abadi Utara yang mengalami keracunan ringan berjumlah $28,4 \%$ (23 orang petani). Tidak ada perbedaan pada aspek aktifitas enzim cholinesterase darah antara kelompok petani Bumijaya II dan Bumi Abadi Utara. Hal tersebut dikarenakan teknik penyemprotan pestisida dari kedua kelompok petani tersebut sama.

Pemakaian kelengkapan APD sesuai aturan merupakan salah satu upaya pengendalian risiko bahaya dalam keselamatan dan kesehatan kerja (K3). Beberapa upaya pengendalian risiko selain alternatif pemakaian kelengkapan APD adalah eliminasi, subtitusi, pengendalian secara teknis dan pengendalian secara administratif. Pengendalian dengan cara pemakaian kelengkapan APD merupakan alternatif pengendalian yang terakhir (Ramli, 2011).

Pemakaian kelengkapan APD dalam kegiatan penyemprotan pestisida diluar ruangan telah diatur dalam Peraturan Dirjen PP dan PL tahun 1993 (Novariyanto, 2013). Kelengkapan APD yang dimaksud terdiri dari sepatu boots, baju lengan panjang, celana panjang, topi, sarung tangan dan masker. Berdasarkan hasil penelitian menunjukkan bahwa sebagian besar petani di Dusun Binangun Desa Bumiaji lebih memilih untuk tidak memakai kelengkapan APD sesuai aturan. Keputusan tersebut dikarenakan petani merasa tidak nyaman ketika harus menggunakan kelengkapan APD sesuai aturan saat melakukan aktifitas penyemprotan pestisida. Petani pada kelompok Bumijaya II yang memakai kelengkapan APD sesuai aturan berjumlah $12,3 \%$ (10 orang petani) dan petani pada kelompok Bumi Abadi Utara yang memakai kelengkapan APD sesuai aturan 
sebanyak $7,4 \%$ ( 6 orang petani). Beberapa upaya pengendalian risiko selain alternatif pemakaian kelengkapan APD adalah eliminasi, subtitusi, pengendalian secara teknis dan pengendalian secara administratif. Pengendalian bahaya dengan cara pemakaian kelengkapan APD merupakan alternatif yang terakhir (Ramli, 2011). Pengelolaan pestisida yang tepat meliputi tata cara penyimpanan, pencampuran dan pengaplikasian yang tepat. Selain itu ada beberapa faktor lain yang dapat berpengaruh yakni: faktor pengetahuan, pendidikan, pengalaman, lingkungan dan kebiasaan dari masingmasing individu (Sugiarto, 2013).

Perbedaan antara kelompok petani Bumijaya II dan Bumi Abadi Utara ditemukan pada faktor pemakaian kelengkapan APD, kelompok petani Bumijaya II memiliki tingkat kesadaran yang cukup tinggi dalam hal pemakaian kelengkapan APD. Setiap tiga bulan sekali pada kelompok petani Bumijaya II diadakan penyuluhan pertanian yang dilakukan oleh pengurus organisasi. Kelompok petani Bumi Abadi Utara terbentuk kurang lebih satu tahun, sehingga pada kelompok ini perlu adanya usulan diadakannya penyuluhan tentang bahaya kontaminasi pestisida yang diakibatkan oleh pemakaian kelengkapan APD yang tidak sesuai aturan.

Menurut Ramli (2011) menyatakan bahwa setiap 30.000 kali tindakan yang tidak aman maka akan terjadi 1 kali kecelakaan fatal, 30 kali kecelakaan berat, 300 kali kecelakaan serius dan 3000 kali kecelakaan ringan. Dari pernyataan tersebut dapat ditarik kesimpulan bahwa semakin lama penyemprot pestisida Dusun Binangun Desa Bumiaji melakukan kontak dengan pestisida maka dimungkinkan rentan terjadi peristiwa kontaminasi pestisida.

Pada kasus kontaminasi pestisida di Kota Batu terindikasi bahwa faktor status gizi petani dapat berpengaruh terhadap perubahan aktifitas enzim cholinesterase darah. Menurut Djianto
(2012) menyatakan bahwa aktifitas enzim cholinesterase bisa mengalami perubahan akibat asupan gizi yang dikonsumsi petani tidak sesuai anjuran. Beberapa asupan gizi yang dibutuhkan diantaranya mineral, kalori dan protein (Djianto, 2012).

Menurut Djojosumarto dalam Novariyanto (2017), menyatakan bahwa seorang petani penyemprot pestisida yang mengalami keracunan disarankan untuk tidak melakukan kontak secara langsung dengan pestisida dalam kurun waktu tertentu. Berdasarkan faktor lama kerja petani tidak ada perbedaan. Kelompok petani Bumijaya II dan Bumi Abadi Utara memiliki lama kerja (durasi) kurang dari delapan jam perhari. Petani memulai bekerja pada pukul 07.00-11.00 WIB dan 14.00-16.00 WIB.

Berdasarkan hasil analisis regresi ordinal pada Tabel 6 menunjukkan bahwa ada pengaruh antara pemakaian kelengkapan APD terhadap aktifitas enzim cholinesterase darah petani. Hal tersebut terbukti dari nilai $p$. value $(0,00)$ faktor pemakaian kelengkapan APD kurang dari nilai alpha $(0,05)$. Sedangkan faktor lama kerja petani tidak berpengaruh terhadap aktifitas enzim cholinesterase darah, karena nilai $p$. value $(0,98)$ faktor tersebut lebih dari nilai alpha $(0,05)$. Hasil penelitian ini didukung oleh pernyataan dari Asyim (2009), Wanodya (2011) dan Novariyanto (2013), yang menyatakan bahwa petani yang memakai kelengkapan APD tidak sesuai aturan akan berisiko tinggi mengalami perubahan aktifitas enzim cholinesterase darah. Diperkuat oleh pernyataan ini, berdasarkan kajian "Risk Assessment dan Pengendalian Risiko pada Sektor Pertanian” Ernawati (2013), menyatakan bahwa pemakaian kelengkapan APD dapat mengurangi risiko dari bahaya kontaminasi pestisida ke dalam tubuh. Faktor lama kerja petani tidak berpengaruh, dikarenakan dalam satu hari bekerja petani tidak hanya melakukan penyemprotan pestisida saja. Kegiatan lain yang dilakukan petani adalah melakukan pemupukan tanaman, pembuatan sarana 
irigasi kebun dan pembibitan tanaman hias. Sehingga waktu kontak terhadap pestisida berkurang (Rahmawati, 2014).

Menurut Desimal (2013) dan Rahmawati (2014), memperkuat hasil penelitian ini, yang menyatakan bahwa faktor lama kerja petani tidak berpengaruh terhadap perubahan aktifitas enzim cholinesterase darah. Pada kedua penelitian sebelumnya terdapat argumentasi bahwa aktifitas enzim cholinesterase darah dapat berangsur angsur meningkat dalam kurun waktu dua minggu, sehingga teori lama kerja dapat mempengaruhi aktifitas enzim cholinesterase darah dapat terbantahkan.

Hasil penelitian ini bertentangan dengan hasil penelitian dari Rahmawati (2014), yang menyatakan bahwa tidak ada pengaruh antara faktor penggunaan APD terhadap aktifitas enzim cholinesterase darah petani. Adanya ketidaksesuaian hasil penelitian dikarenakan terdapat perbedaan dalam pengkategorian data pada variabel (faktor) penggunaan APD. Sebelum melakukan analisis regresi ordinal perlu dilakukan uji multikolinearitas. Hal ini dilakukan sebagai persyaratan dalam analisis regresi ordinal. Fungsi dari uji multikolinearitas untuk melihat hubungan antara faktor, apabila faktor - faktor dalam penelitian saling berhubungan maka akan berdampak pada hasil regresi ordinal yang kurang valid (Iban, 2017). Berdasarkan hasil uji multikolinearitas pada Tabel 5, faktor-faktor dalam penelitian tidak saling berhubungan. Sehingga metode regresi ordinal dapat memberikan hasil yang valid.

Berdasarkan hasil analisis regresi ordinal (tabel 5) didapatkan model sebagai berikut:

$$
\begin{gathered}
\beta_{0}=-2,675 \\
\beta_{1}=-5,652 \\
P_{i}=\frac{1}{\beta_{0}+\beta_{1} X_{1}+\beta_{2} X_{2}+\cdots+\beta_{i} X_{i}} \\
P_{i}=\frac{1}{-2,675-5,652 X_{1}}
\end{gathered}
$$

Berdasarkan model yang didapat, $P_{i}$ merupakan variabel dependen penelitian (aktifitas enzim cholinesterase darah). $\quad X_{i}$ merupakan variabel independen / faktor penelitian (pemakaian kelengkapan APD). Interpretasi model regresi ordinal: Pengkodean: Pemakaian kelengkapan APD sesuai aturan $\left(X_{1}\right)=1$. Pemakaian kelengkapan APD tidak sesuai $\left(X_{0}\right)$ aturan $=0$ Maka didapatkan persamaan sebagai berikut:

$$
\begin{aligned}
& P_{i}=\frac{1}{-2,675-5,652(1)} \\
& P_{i}=\frac{1}{(-8,327)}=-0,12
\end{aligned}
$$

Tabel 7. Hasil Uji Pseudo $R^{2}$

\begin{tabular}{cc}
\hline Statistik Uji & Nilai \\
\hline McFadden & 0,326
\end{tabular}

Berdasarkan model regresi ordinal yang didapat maka petani yang memakai kelengkapan APD sesuai aturan dalam proses penyemprotan pestisida memiliki risiko tidak mengalami perubahan aktifitas enzim cholinesterase darah sebesar 0,12 kali lebih besar dibanding petani yang memakai kelengkapan APD tidak sesuai aturan. Berdasarkan analisis regresi ordinal terdapat beberapa uji parameter untuk mengetahui ketepatan dari model regresi ordinal (Nanda., Surya., dan Darma; 2012) Parameter tersebut yakni : Uji Pseudo $R^{2}$. Berdasarkan hasil uji Pseudo $R^{2}$ pada tabel 7 dapat disimpulkan bahwa faktor pemakaian kelengkapan APD pada model regresi ordinal mampu menjelaskan variasi dari variabel dependen penelitian (aktifitas enzim cholinesterase darah) sebesar $32,6 \%$; sedangkan $67,4 \%$ merupakan faktor lain yang tidak diteliti dalam penelitian ini. Sehingga dapat disimpulkan bahwa faktor pemakaian kelengkapan APD berdampak signifikan dalam mencegah kasus kontaminasi pestisida.

\section{SIMPULAN}

Mayoritas petani di Dusun Binangun Desa Bumiaji memiliki aktifitas 
enzim cholinesterase darah pada kategori keracunan ringan. Proporsi keracunan ringan pada kelompok petani Bumi Jaya II lebih rendah dibandingkan kelompok petani Bumi Abadi Utara. Sebagian besar petani tidak memakai kelengkapan APD sesuai aturan, dan memiliki lama kerja kurang dari 8 jam per hari. Ada pengaruh antara pemakaian kelengkapan APD terhadap aktifitas enzim cholinesterase darah petani tanaman hias dan holtikulutra yang menggunakan pestisida. Berdasarkan model regresi ordinal yang tersusun dapat disimpulkan bahwa petani yang memakai kelengkapan APD sesuai aturan pada saat penyemprotan pestisida, maka akan berpeluang lebih besar untuk tidak mengalami perubahan aktifitas enzim cholinesterase darah sebesar 0,12 kali dibandingkan petani yang tidak memakai kelengkapan APD sesuai aturan. Sedangkan faktor lama kerja petani tidak berpengaruh terhadap aktifitas enzim cholinesterase darah.

Model regresi ordinal yang terbentuk, yakni:

$$
\begin{aligned}
P_{i} & =\frac{1}{-2,675-5,652 X_{1}} \\
P_{i} & =\frac{1}{-2,675-5,652(1)} \\
P_{i} & =\frac{1}{(-8,327)}=-0,12
\end{aligned}
$$

Pengurus kelompok petani Bumijaya II dan Bumi Abadi Utara perlu mengadakan kegiatan sosialisasi pemakaian kelengkapan APD yang sesuai aturan pada anggotanya (memakai sepatu boots, baju lengan panjang, celana panjang, topi, sarung tangan dan masker). Bagi Dinas Kesehatan Kota Batu perlu melakukan tindakan promosi kesehatan dalam upaya preventif kasus kontaminasi pestisida pada petani. Beberapa cara yang bisa digunakan adalah penyuluhan kesehatan, membuat media poster dan leaflet kesehatan petani (Hasibuan, 2015).

Pada pihak pengurus desa perlu adanya sosialisasi tindakan preventif kasus kontaminasi pestisida kepada masyarakatnya. Sosialisasi tersebut dapat dilakukan pada saat acara pengajian, acara 17 agustus dan lain-lain. Sedangkan untuk peneliti selanjutnya perlu adanya penambahan faktor lain yang diteliti untuk mengetahui faktor - faktor yang berpengaruh terhadap aktifitas enzim cholinesterase darah. Salah satu contonya penambahan faktor lingkungan dalam kaitan kasus kontaminasi pestisida.

\section{DAFTAR PUSTAKA}

Abdhidama. 2015. Pemodelan Tingkat Katarak Dengan Pendekatan Regresi Logistik Ordinal. Jurnal Biosains. Surabaya, Universitas Airlangga.

Asyim. 2009. Hubungan Antara Alat Pelindung Diri (APD) Dengan Aktifitas Cholinesterase Darah. Jurnal Kesling. Surabaya, Poltekkes Surabaya.

Desimal. 2013. Pengaruh Paparan Pestisida Organofosfat Terhadap Aktifitas Enzim Kolinesterase Pada Petani Penyemprot Apel Di Desa Bumiaji Kecamatan Bumiaji Kota Batu. Jurnal Kesling. Surabaya, Universitas Ailangga.

Dinas Kesehatan Kota Batu. 2017. Laporan Hasil Pemeriksaan Cholinesterase. Batu, Dinkes Batu.

Djianto. W. 2012. Hubungan Asupan Gizi Petani Dengan Perubahan Enzim Cholinesterase darah di Kota Batu. Jurnal Gizi. Surabaya, Poltekkes Surabaya.

Ernawati, D., Tualeka, A.R 2013. Risk Assessment dan Pengendalian Risiko pada Sektor Pertanian (Studi Kasus di Pertanian Bawang Merah Desa Kendalrejo, Kecamatan Bagor, Kabupaten Nganjuk). The Indonesian Journal Of Occupational Safety And Health, Volume 2 Nomor 2, hal. 154-161. Surabaya, Universitas Airlangga.

Fattah. 2013. Analisis Faktor-faktor yang Mempengaruhi Masa Studi 
Lulusan Mahasiswa Program Magister Institut Teknologi Sepuluh Nopember (ITS) Surabaya Menggunakan Regresi Logistik Ordinal dan Regresi Probit Ordinal. Jurnal Statistika. Surabaya: Fakultas MIPA Institut Teknologi Sepuluh Nopember.

Greene, W.H. 2012. Econometric analysis. New York: New York University.

Hasibuan, 2015. Hubungan Penggunaan Alat Pelindung Diri Dengan Gejala Keracunan Pada Penyemprot Pestisida Di Perkebunan Kelapa Sawit Tanjung Garbus Pagar Merbau PTPN II. Skripsi. FKMUSU, Medan, Rhineka.

Iban. 2017. Perbandingan Analisis Regresi Ordinal Model Logit Dan Probit Pada Faktor Ibu Yang Mempengaruhi Berat Badan Lahir Rendah. Jurnal Biometrika dan Kependudukan. Surabaya, Universitas Airlangga.

Karyadi. 2008. Dampak penggunaan pupuk dan pestisida yang berlebihan terhadap kandungan residu tanah pertanian bawang merah di Kecamatan Gemuh Kabupaten Kendal. Agromedia. Jurnal Kesehatan Masyarakat. Jember, Universitas Jember. volume 26 No.1; pp 10-19.

Guntur, K. 2014. Pedoman Praktikum Laboratorium Keselamatan dan Kesehatan Kerja. Semarang. Undip.

Nanda., S., Darma. 2012. Pemilihan Model Regresi Logistik Multinomial dan Regresi Ordinal Terbaik Berdasarkan $\mathrm{R}^{2}$ MC. Fadden. Jurnal Matematika. Malang: Fakultas MIPA Universitas Brawijaya.

Novariyanto, D. 2013. Hubungan Antara Pemakaian Alat Pelindung Diri Dengan Aktifitas Enzim Cholinesterase Darah. Jurnal Kesling. Surabaya, Poltekkes Surabaya.
Novariyanto, D. 2017. Pemodelan Faktor Yang Berpengaruh Terhadap Aktifitas Enzim Cholinesterase Darah Dengan Pendekatan Metode Regresi Ordinal. Skripsi. Surabaya. Fakultas Kesehatan Masyarakat, Universitas Airlangga.

Palupi, W.G.G. 2013. Perbandingan model logistik Ordinal dengan regresi model probit terhadap faktor-faktor yang mempengaruhi sikap siswa smp pada mata pelajaran matematika. Jurnal online Universitas Negeri Malang.

Rahmawati, Y. 2014. Pengaruh Antara Faktor Karakteristik Petani Terhadap Aktifitas Enzim Cholinesterase Darah. The Indonesian Journal of Public Health. Surabaya. Universitas Airlangga.

Raini. 2007. Toksikologi Pestisida dan Penanganan Akibat Keracunan Pestida. Jurnal Online, Media Litbang Kesehatan Volume XVII Nomor 3, Jakarta. Trisuna.

Ramli, S. 2011. Pedoman Praktis Manajemen Risiko. Jakarta, Dian Rakyat. Cet -2 .

Sugiarto. M. 2013. Faktor Yang Berhubungan Dengan Aktifitas Enzim Cholinesterase Darah Petani. Jurnal Kesling. Surabaya, Poltekkes Surabaya.

Sutrisna, R. 2011. Pestisida, Yogyakarta. Kanisius.

Qudratullah, F. 2013. Analisis Regresi Terapan Teori, Contoh Kasus dan Aplikasi dengan SPSS. Yogyakarta. Andi.

Wanodya, E. 2011. Hubungan Faktor Karakteristik Dan Kelengkapan APD Dengan Kadar Cholinesterase Dalam Darah. Jurnal Kesling. Surabaya, Poltekkes Surabaya.

Wibowo, P. 2017, Panduan Praktis Penggunaan Pupuk dan Pestisida. Jakarta, Penebar Swadaya. 